Ruminant Research

Manuscript Number:

Title: Culicoides biting midges in spain: a brief overview

Article Type: SI: XL SEOC Congress

Keywords: Culicoides; biting midges; vector; bluetongue; control; Spain.

Corresponding Author: Mr. Pedro María Alarcón Elbal, M.Sc.

Corresponding Author's Institution: Universidad de Zaragoza

First Author: Javier Lucientes, Ph.D.

Order of Authors: Javier Lucientes, Ph.D.; Pedro María Alarcón Elbal, M.SC.

Abstract: The number of studies on insects of genus culicoides Latreille, 1809 (Diptera, Ceratopogonidae) has increased considerably in spain since 2000, mainly due to their role as vectors of arboviruses that cause disease in animals, especially ruminants. This paper aims to expose some general considerations about Culicoides biting midges in Spain. 


\section{Culicoides biting midges in Spain: a brief overview.}

2

3 J. Lucientes ${ }^{\mathrm{a},{ }^{*},}$, P.M. Alarcón-Elbal ${ }^{\mathrm{a}}$

4

5 a Department of Animal Pathology, Faculty of Veterinary, University of Zaragoza, Zaragoza, 6 Spain.

$7 \quad{ }^{*}$ Corresponding author at: C/ Miguel Servet, 177. Zip Code: 50013, Zaragoza, Spain. Tel.: +34 897676 1560.E-mail address: jlucien@unizar.es

11 The number of studies on insects of genus Culicoides Latreille, 1809 (Diptera,

12 Ceratopogonidae) has increased considerably in Spain since 2000, mainly due to their role as 13 vectors of arboviruses that cause disease in animals, especially ruminants. This paper aims to 14 expose some general considerations about Culicoides biting midges in Spain.

15 Keywords: Culicoides; biting midges; vector; bluetongue; control; Spain.

17 Biting midges of the genus Culicoides Latreille, 1809 (Diptera: Ceratopogonidae) (Diptera, 18 Ceratopogonidae) are minute haematophagous flies with veterinary relevance as vectors of 19 internationally important arbovirus of livestock (Mellor et al., 2000). The greatest economic 20 impact of Culicoides lies in their ability to transmit bluetongue virus (BTV), but also other 21 arboviruses with interest in ruminant health as the recently emerged Schmallenberg virus (SBV) 22 (Harrup et al., 2015). Regarding bluetongue, the infection ranges from asymptomatic, in the vast 23 majority of infected animals, to fatal, in a proportion of infected sheep, goats, deer and some 24 wild ruminants. Additional economic costs result from surveillance and control programs, 25 reproductive losses, damaged wool and decreased milk production. The existence of multiple 26 serotypes complicates control, as immunity to one serotype may not be cross-protective against 27 others (CFSPH, 2015). In fact, twenty seven BTV serotypes have been recognized worldwide, 
including ten from Europe (Jencke et al., 2015). Since 2000, four of these serotypes have been

29 found in Spain (Rodríguez-Sánchez et al., 2010).

30 In the "Old World", bluetongue had been linked traditionally with the presence of C. imicola.

31 However, in 2006 BTV-serotype 8 was reported from the countries in Northern and Western

32 Europe (Thiry et al., 2006) where the species was not present, suggesting the possibility of other

33 midge species could be involved in the transmission, especially in cooler regions. Nowadays, it

34 is known that the European vectors for BTV are various species of Culicoides midges, most, but

35 not all, from the subgenus Avaritia Fox, 1955: Culicoides obsoletus complex (C. obsoletus and

36 C. scoticus), C. chiopterus, C. dewulfi, Culicoides pulicaris complex (C. pulicaris and C.

37 lupicaris) and C. imicola. Other species such as C. montanus, C. punctatus, C. newsteadi and C.

38 nubeculosus have been found positive to BTV genome, but their role in transmission is still

39 unclear (Goffredo et al., 2015). The last update shows a total of 82 species of Culicoides in

40 Spain (Sánchez Murillo et al., 2015), being all the above-mentioned reported in the country.

41 Taking into account the distribution range of the main vector species, C. imicola is well

42 distributed across the dry Mediterranean area, while C. obsoletus complex is most abundant in

43 the fully humid climates of Central and Northern Europe (Brugger and Rubel, 2013). In our

44 country, C. imicola is mainly present in the drier Central and South-western part of continental

45 Spain and mostly absent from the Northern more humid part. Occasionally, some specimens

46 were also caught along the Ebro Valley and along the North-eastern Mediterranean coast, even

47 sporadically in the Basque Country (Goldarazena et al., 2008). The population of this

48 ceratopogonid peaks in the September-October period and it seems directly related to summer

49 rainfall and soil texture (Alarcón-Elbal, 2015). The species has been reported entering into

50 livestock premises (Calvete et al., 2009), although normally exhibits an exophagic behaviour

51 (Barnard, 1997). On the other hand, C. obsoletus complex is the most widespread group

52 suggesting they may adapt to a wider range of eco-climatic circumstances than the other

53 species, although the highest densities have been recorded in Northern Spain. The population of

54 this species group peaks especially in May-June and then in mid-October, and it seems directly 
related with the presence of bovine hosts and substrates associated to livestock as breeding sites (Alarcón-Elbal, 2015). Adults show some degree of endophagy (Viennet et al., 2013).

In general, breeding sites of Culicoides species are poorly known. These Diptera can breed in a wide range of soils, if they provide enough moisture and organic matter to allow the development of the preimaginal stages, although each species has different preferences (Zimmer et al., 2013). Culicoides imicola has been observed to prefer semi-moist breeding sites, and has been found in drainage canals and puddles created by leakage from water pipes, where soils are not subject to flooding (Mellor and Pizolis, 1979; Foxi and Delrio, 2010). Meanwhile, $C$. obsoletus can develop in a wide range of habitats, including moist forest leaf litter, tree holes, standing water and marsh edges with vegetation, swamps, cattle manure and horse dung, among others (Ninio et al., 2011; González et al., 2013). The immature habitats of C. scoticus may coexist with C. obsoletus fairly regularly (Conte et al., 2007).

Carpenter et al. (2008) detail five main methods of controlling Culicoides midges: (a) application of insecticides and pathogens to larval habitats; (b) environmental interventions to remove larval habitats; (c) controlling adult midges by treating either resting sites, such as animal housing, or host animals with insecticides; (d) housing livestock in screened buildings, and; (e) using repellents or host kairomones to lure and kill adult midges.

Regarding the methods of larval control (a) and (b), a better knowledge of the microhabitats of Culicoides biting midges may allow the development of targeted species-specific vector control strategies (Zimmer et al., 2013). To date, no insecticidal products have been authorized specifically against Culicoides in the EU, although a wide range of products are available, licensed and in use against other arthropods of veterinary importance. Under restricted situations it may be feasible to reduce Culicoides populations by treatment of their breeding sites with the application of insecticides, but the high residual effect over other related species, animals and plants, resulted in a decline in the number of agents available for livestock pest management (EFSA, 2008). In order to minimize Culicoides breeding where possible, certain hygienic measures should be taken such as removal of animal litter, avoid drinking trough overflowing, take manure away from farm setting or dry or cover it with canvas, reduction of 
83 silage residues and treatment with methods such as composting and acidification (Zimmer et al.,

84 2013; González, 2014).

85 In general, aerial and/or broad-scale ultra-low volume (ULV) spraying against adult Culicoides with insecticides (c) is unlikely to be environmentally acceptable. The direct application of insecticides to livestock present some drawbacks such as the need to calculate the optimal lethal doses, achieving optimal dispersal of the insecticide over the whole skin and taking into account the physiological characteristics of the animal (González, 2014). Nonetheless, vector control using residual spraying or application to livestock is recommended by many authorities to reduce BTV transmission (Venail et al., 2011). In this sense, some field trials that have assessed deltamethrin pour-on of livestock show a significant decrease in Culicoides feeding rates under field conditions for at least 35 day (Weiher et al., 2014), which is particularly relevant in situations when vaccination against BTV is not feasible such as with emergence of new serotypes of the virus. Additionally, deltamethrin, as well as many other synthetic pyrethroids has a significant repellent effect on certain ectoparasites.

Protective housing (d) has been investigated as a means of shielding animals from the majority of Culicoides attacks and hence arbovirus transmission, but the efficacy of this method can be difficult to estimate because the types and security of animal housing vary widely (Carpenter et

100 al., 2008). Reducing biting risk through stabling appears to be a useful strategy for at least some

101 livestock species, although it is almost impossible to cover all the entries in the livestock sheds.

102 In addition, it is needed further research about the exophilic/endophilic behaviour of the 103 Culicoides present in each area (González, 2014).

104 Successful studies with repellents (e) (synthetic, natural repellents and non-host volatiles) have 105 been performed in laboratory and field experimentation. However, absorption through the skin may reduce the effectiveness of these compounds and lead to potential problems of adverse

107 reactions in the livestock and considerations of milk and meat withdrawal times (Carpenter et

108 al., 2008). Otherwise, there has been an increasing interest in pull strategies with a proliferation 109 of trap designs, but these are currently insufficiently developed for the reduction of the 110 population of Culicoides over a large area (González, 2014). 
111 In conclusion, for many Culicoides species, most aspects on their ecology and behaviour remain

112 undefined, and it hampers future control efforts. The consensus is that a holistic control strategy

113 is needed. In particular, the combination of insecticides, attractants and repellents could provide

114 an optimal control strategy, but further research is required on how this could be achieved for

115 many different vector species (Logan et al., 2010).

116

\section{REFERENCES}

118 Alarcón-Elbal, P.M., 2015. Estudio de los dípteros mamófilos del género Culicoides Latreille, 1191809 (Diptera, Ceratopogonidae) potenciales vectores de patógenos al ganado en Castilla-La 120 Mancha [Ph.D. Thesis]. University of Zaragoza, Spain.

121 Barnard, B.J.H., 1997. Some factors governing the entry of Culicoides spp. (Diptera:

122 Ceratopogonidae) into stables. Onderstepoort J. Vet. Res. 64(3), 227-233.

123 Brugger, K., Rubel, F., 2013. Characterizing the species composition of European Culicoides 124 vectors by means of the Köppen-Geiger climate classification. Parasit. Vectors 6, 333.

125 Calvete, C., Estrada, R., Miranda, M.A., del Río, R., Borràs, D., Beldron, F.J., Martínez, A., 126 Calvo, A.J., Lucientes, J., 2009. Entry of bluetongue vector Culicoides imicola into livestock 127 premises in Spain. Med. Vet. Entomol. 23, 202-208.

128 Carpenter, S., Mellor, P.S., Torr, S.J., 2008. Control techniques for Culicoides biting midges 129 and their application in the U.K. and northwestern Palaearctic. Med. Vet. Entomol. 22, 175130187.

131 CFSPH (The Center of Food Security and Public Health), 2015. Bluetongue. Last Updated: 132 June 2015. Available at: http://www.cfsph.iastate.edu/Factsheets/pdfs/bluetongue.pdf 133 [Accessed 25 Nov 2015]

134 Conte, A., Ippoliti, C., Savini, L., Goffredo, M., Meiswinkel, R., 2007. Novel environmental 135 factors influencing the distribution and abundance of Culicoides imicola and the Obsoletus 136 complex in Italy. Vet. Ital. 43(3), 571-580. 
137 Ducheyne, E., Miranda Chueca, M.A., Lucientes, J., Calvete, C., Estrada, R., Boender, G.J., 138 Goossens, E., De Clercq, E.M., Hendrickx, G., 2013. Abundance modelling of invasive and 139 indigenous Culicoides species in Spain. Geospat. Health 8(1), 241-254.

140 EFSA, 2008. Scientific opinion of the panel on animal health and welfare on a request from the

141 European commission (DG SANCO) on bluetongue. EFSA J. 735, 1-70.

142 Foxi, C., Delrio, G., 2010. Larval habitats and seasonal abundance of Culicoides biting midges 143 found in association with sheep in northern Sardinia, Italy. Med. Vet. Entomol. 24, 199-209.

144 Goffredo, M., Catalani, M., Federici, V., Portanti, O., Marini, V., Mancini, G., Quaglia, M., 145 Santilli, A., Teodori, L., Savini, G., 2015. Vector species of Culicoides midges implicated in the 146 2012-2014 Bluetongue epidemics in Italy. Vet. Ital. 51(2), 131-138.

147 Goldarazena, A., Romón, P., Aduriz, G., Balenghien, T., Baldet, T., Delécolle, J.C., 2008. First 148 record of Culicoides imicola, the main vector of bluetongue virus in Europe, in the Basque 149 Country (northern Spain). Vet. Rec. 162, 820-821.

150 González, M., 2014. El género Culicoides (Diptera: Ceratopogonidae) en el País Vasco, norte 151 de España [Ph.D Thesis]. University of Basque Country, Spain.

152 González, M., López, S., Mullens, B.A., Baldet, T., Goldarazena, A., 2013. A survey of 153 Culicoides developmental sites on a farm in northern Spain, with a brief review of immature 154 habitats of European species. Vet. Parasitol. 191(1-2), 81-93.

155 Harrup, L.E., Bellis, G.A., Balenghien, T., Garros, C., 2015. Culicoides Latreille (Diptera: 156 Ceratopogonidae) taxonomy: Current challenges and future directions. Infect. Genet. Evol. 30, $157 \quad 249-266$.

158 Jenckel, M., Bréard, E., Schulz, C., Sailleau, C., Viarouge, C., Hoffmann, B., Höper, D., Beer, 159 M., Zientara, S., 2015. Complete coding genome sequence of putative novel bluetongue virus 160 serotype 27. Genome Announc. 3(2): e00016-15.

161 Logan, J.G., Cook, J.I., Mordue Luntz, A.J., Kline, D.L., 2010. Understanding and exploiting 162 olfaction for the surveillance and control of Culicoides biting midges (Ceratopogonidae). In: 163 Takken, W., Knols, B.G.J. (Eds.), Ecology and control of vector-borne diseases (2): olfaction in 164 vector-host interactions. Wageningen Academic, Wageningen, 10: 217-246 
165 Mellor, P.S., Boorman, J., Baylis, M., 2000. Culicoides biting midges: their role as arbovirus

166 vectors. Ann. Rev. Entomol. 45, 307-340.

167 Mellor, P.S., Pitzolis, G., 1979. Observations on breeding sites and light trap collections of

168 Culicoides during an outbreak of bluetongue in Cyprus. Bull. Entomol. Res. 69, 229-234.

169 Ninio, C., Augot, D., Dufour, B., Depaquit, J., 2011. Emergence of Culicoides obsoletus from 170 indoor and outdoor breeding sites. Vet. Parasitol. 183(1-2), 125-129.

171 Rodríguez-Sánchez, B., Gortázar, C., Ruiz-Fons, F., Sánchez-Vizcaíno, J.M., 2010. Bluetongue

172 Virus Serotypes 1 and 4 in Red Deer, Spain. Emerg. Infect. Dis. 16(3), 518-520.

173 Sánchez Murillo, J.M., González, M., Martínez Díaz, M.M., Reyes Galán, A. Alarcón-Elbal, 174 P.M., 2015. First record of Culicoides paradoxalis Ramilo \& Delécolle, 2013 (Diptera, 175 Ceratopogonidae) in Spain. Graellsia 71(2), e033.

176 Thiry, E., Saegerman, C., Guyot, H., Kirten, P., Losson, B., Rollin, F., Bodmer, M., Czaplicki, 177 G., Toussaint, J.F., De Clercq, K., Dochy, J.M., Dufey, J., Gilleman, J.L., Messeman, K., 2006. 178 Bluetongue in northern Europe. Vet. Rec. 159, 327.

179 Venail, R., Mathieu, B., Setier-Rio, M.L., Borba, C., Alexandre, M., Viudes, G., Garros, C., 180 Allene, X., Carpenter, S., Baldet, T., Balenghien, T., 2011. Laboratory and field-based tests of 181 deltamethrin insecticides against adult Culicoides biting midges. J. Med. Entomol. 48(2), 351182357.

183 Viennet, E., Garros, C., Gardès, L., Rakotoarivony, I., Allène, X., Lancelot, R., Crochet, D., 184 Moulia, C., Baldet, T., Balenghien, T., 2013. Host preferences of Palaearctic Culicoides biting 185 midges: implications for transmission of orbiviruses. Med. Vet. Entomol. 27(3), 255-266.

186 Wehier, W., Bauer, B., Mehlitz, D., Nijhof, A.M., Clausen, P.H., 2014. Field trials assessing 187 deltamethrin (Butox $\left.{ }^{\circledR}\right)$ treatments of sheep against Culicoides species. Parasitol. Res. 113, $188 \quad 2641-2645$.

189 Zimmer, J.Y., Losson, B., Saegerman, C., Haubruge, E., Francis, F., 2013. Breeding sites and 190 species association of the main Bluetongue and Schmallenberg virus vectors, the Culicoides 191 species (Diptera: Ceratopogonidae), in Northern Europe. Ann. Soc. Entomol. Fr. 49(3), 335192344. 